VLAD ȚOCA

\title{
ROMANIAN ART HISTORIOGRAPHY \\ IN THE INTERWAR PERIOD. \\ BETWEEN THE SEARCH FOR SCHOLARSHIP AND COMMITMENT TO A CAUSE
}

In Romania, the interwar period was a period of great effervescence, of dramatic changes and of great development in social and economic terms. In the wake of World War I, Romania emerged as a large nation-state incorporating new territories such as Transylvania, Bessarabia and Bukovina. The period saw the rise of the middle class, still relatively small, but which became an important force in both the economic and political life of the country. ${ }^{1}$ The new ruling classes after the war experimented with new ideas in the economy, in politics, in literature and the arts. ${ }^{2}$ The emerging urban middle class needed new institutions and the re-ordering of those that had been well established, questioned and challenged old traditions.

The two decades between the two world wars were also a troubled time, with democracy being challenged and far-right movements making their way in politics and society. The Romanian state was permanently looking for the best way to preserve the newly created national state and defend its frontiers. This was the only matter all Romanian parties, apart from the Communist party, seemed to agree on. ${ }^{3}$ The threat of territorial revisionism coming from Hungary, the Soviet Union and, to a lesser extent, Bulgaria, united all political actors, the Liberals, the National Peasants and king Carol II, in defending the Versailles peace treaty system and in supporting the League of Nations as the guarantor of this peace and stability. The peace settlement reached at Versailles was far from perfect, as these territories came with substantial minorities, which caused constant troubles with the above-mentioned neighbouring states. Most Romanians believed that historical justice had been achieved

\footnotetext{
${ }^{1}$ K. Hitchins, A Concise History of Romania, Cambridge 2014, p. 159.

2 Ibidem.

3 Ibidem, p. 195.
} 
at last and that all the newly incorporated territories had been inhabited by Romanians since time immemorial, therefore it was only natural that they become part of the "Mother country."

The Hungarians living in Romania as well as those in Hungary resented the loss of Transylvania and the Banat and never missed a chance to stake their claims to those lost territories, which had been part of their kingdom for several centuries. In Hungary coordinated state propaganda was directing all means available in order to push this cause. Historical arguments were very important, and these were delivered continuously. The Hungarian voice was heard in Western media, books were published and sent to libraries and decisionmakers abroad, while at the League of Nations, their pleas were repeated ceaselessly. Soviet Russia also desired territories lost at the end of the war, and the Romanian Communist Party, founded in 1921, included in its program the need to free the subjugated peoples in the country by breaking apart several territories. This was, in fact, the main argument the government offered for outlawing the party soon after its creation.

In this context, historical arguments became political arguments used by the Romanians in order to justify the new territorial gains and the Versailles peace treaties system. Art history, part of the family of historical disciplines came to play an important part in this.

The period between the two world wars was dominated by what Keith Hitchins calls the Great Debate, ${ }^{4}$ about national identity and development. The opponents were those advocating synchronism with the West, on the one hand, and those pleading for tradition, on the other, with many others looking for a third way. This debate between Europeanist and the traditionalist was reflected in the way politics and economic policies were conducted, in the shaping of institutions and life in general. This debate had been going on in Romanian society since the second half of the $19^{\text {th }}$ century. In the interwar period, two important figures, Eugen Lovinescu and Ștefan Zeletin, shaped the thinking of the Europeanists. Lovinescu advocated "synchronism," the modernisation of the country by adopting the West's institutions, ethics and methods, while Zeletin had a more materialist view seeing Romania bonded inextricably to western capitalism. The traditionalists, on the other hand, looked for models in the country's past and traditions, real or imagined, as they stood against the import of western institutions and forms. It is ironical that their ideas were, in fact, an import coming from the west at the turn of the century. Nichifor Crainic emphasized Orthodoxy and its importance for generating a national revival. Lucian Blaga and his colleagues at the Gândirea

\footnotetext{
${ }^{4}$ Ibidem, p. 160 sqq.
} 
review looked beyond Orthodoxy, although acknowledging its importance, searching for the popular psyche as revealed in folklore and mythology, oriental religions, but also in contemporary philosophy and sociological thinking in Western Europe. ${ }^{5}$

Nevertheless, it is difficult to draw a line dividing these currents of thought. In literature and mostly in poetry, the blending of all these directions is striking and telling. Such poets like Tudor Arghezi, Lucian Blaga, and Ion Pillat, although achieving synchronism and becoming international to a great extent, drew inspiration from tradition.

In Romanian interwar culture, the country's modernity was emphasised in order to place the country in the large family of European nations. An opposing and, at the same time, complementary line of thought was that of presenting the long and noble Romanian history, tradition and ancestral roots. Romania, like many of the other young countries of the region, felt it did not truly belong to the European family and felt its very existence threatened. The need to demonstrate this belonging emphasised the effort to reconstruct or reinvent a long, remarkable and continuous history for the more distant past, and, at the same time, to present a modern, civilised and European society when discussing about the more recent times.

These two themes have been present in Romanian culture since the mid$19^{\text {th }}$ century. They were used by various authors, sometimes in a complementary fashion, while at others, in a conflicting manner in literature, historical writing or political discourse. This process did not end with the creation of Greater Romania after the conclusion of World War I. New threats, mentioned above, maintained the need to continue this discourse.

All these ideas and evolutions in recent history are reflected in Romanian historiography, and art historical writing is part of this process. In Romanian culture, art historical writing did not exist as such until the end of the $19^{\text {th }}$ century. It was only in the first years of the next century that the number of scholarly works produced in line with western standards steadily increased. As part of a general tendency of aligning Romanian academic practices with those in the west, at that time art historiography established itself as a respectable academic discipline, a process which went hand in hand with the establishment of new institutions such as museums, university departments (art history seminars), research institutions and the Commission for historical monuments. All of these institutions were founded and financed by the Romanian state, which made the scholars working there civil servants employed by the state, meaning that whether they liked

\footnotetext{
5 Ibidem, p. 162.
} 
it or not, these specialists were bound to the state and its policies, as were many of their colleagues throughout Europe. ${ }^{6}$ It is not easy to prove that there was any direct pressure, since these institutions were academic bodies and their purpose was to encourage a scholarly and impartial approach in the service of historical truth. There are, nevertheless, numerous indications that in some cases we are dealing with art historians with an agenda, fighting for a cause, while, in others, the general ideas debated in Romanian society made their way into scholars' writings. In several texts (ranging from press articles to popularisation brochures intended for the general public or even scholarly texts), the most prominent art historians of the day strongly affirm the necessity of serving the national cause through their writings. In this paper, we will be looking at the general histories written between the two world wars dealing with Romanian art as a whole or of different geographical areas. The choice of these texts is motivated by the fact that these works are the result of larger research projects and have a broader scope and as such better summarise the trends of the interwar period. From the cultural point of view, the interwar period continued through World War II and the few years after its end, until the communist regime was installed. Therefore, several texts written in the war years are included here.

The most numerous and consistent investigations carried out between the two world wars were those about Romanian old art, which refers to the time of the first documented monuments in Wallachia and Moldavia until the beginning of the early $1800 \mathrm{~s}$. Starting with the middle of the $19^{\text {th }}$ century, the first writings were mostly literary references to monuments and were made in the spirit of romanticism and national awakening that characterised that period. A momentous change was brought about by the creation of the Commission for historic monuments on November $17^{\text {th }} 1892$. Its declared purpose, apart from creating an inventory of monuments in order to protect them, was that of elaborating studies that would lead to a better understanding of medieval art in Romania. ${ }^{7}$ The initial efforts were oriented towards architecture, because old buildings seemed to be the most threatened by neglect or by arbitrary restoration and remodelling. Soon the investigation of other domains

${ }^{6}$ See: J. Bakoš, "From Universalism to Nationalism. Transformation of Vienna School Ideas in Central Europe," in: Die Kunsthistoriographien in Ostmitteleuropa und der nationale Diskurs, eds. R. Born, A. Janatková, A. S. Labuda, Berlin 2004.

7 I. Opriș, Ocrotirea patrimoniului cultural. Tradiții. Destin. Valoare, București 1986, pp. 104-105. 
followed, such as painting, sculpture or decorative arts. In a relatively short time, these efforts paid off and a general picture of old Romanian art began to take shape, a larger puzzle made up of smaller fragments, such as descriptions of monuments, notes or on-site observations. In 1908 the Commission began issuing its own publication, the Commission for Historic Monuments' Bulletin (Buletinul Comisiunii Monumentelor Istorice), which was initially intended as a platform for publishing brief or more extensive texts about various monuments, but it soon became a periodical dedicated to old Romanian art in general. This publication was meant "to contribute to the progress of historical, architectural and artistic studies, with a special focus on the monuments of our history, and to remain, for those to come, an archive of faithful icons, under all respects, of the present state of our ancient monuments." ${ }^{8}$ Before the war, several field investigations were carried out that were meant to shed new light on the origins of Romanian art and architecture. This research was conducted in Romania, but also in Constantinople, Mount Athos, Mesembria and Serbia, such as those studies carried out by Gheorghe Balș and Nicolae Ghika-Budești. ${ }^{9}$ After the war, regional issues were printed by the Commission's branches in Cluj and Chișinău.

During World War I, the Bulletin ceased to be issued, but after the conclusion of the conflict it was published again, with a voluminous special edition (for the years 1917-1923), its content being indicative of the broader scope the publication assumed after the war and the type of texts it planned to include from then on. This special issue hosted a number of fundamental texts, such as those detailing the excavations and restoration works in the princely church of St. Nicholas in Curtea de Argeș, carried out by a large team, among whose members it is worth mentioning Virgil Drăghiceanu, ${ }_{10}^{10}$ Dimitrie Onciul, ${ }^{11}$ Nicolae Ghika-Budești ${ }^{12}$ and I. Mihail. ${ }^{13}$ Over the following years, the

8 ***, "Cuvinte începătoare," Buletinul Comisiunii Monumentelor Istorice 1908, 1, p. 5.

9 Gh. Balș, O vizită la câteva biserici din Serbia, București 1911; N. Ghika-Budești, Gh. Balș, "Ruinele bizantine din Mesembria," Buletinul Comisiunii Monumentelor Istorice 1912, 5, pp. 1-22; Gh. Balș, "Notiță despre arhitectura Sfântului Munte," Buletinul Comisiunii Monumentelor Istorice 1913, 6, pp. 1-49.

10 See: V. Drăghiceanu, "Curtea domnească din Curtea de Argeș. Note istorice și arheologice," Buletinul Comisiunii Monumentelor Istorice 1917-1923, 10-16, pp. 9-23.

${ }^{11}$ See: D. Onciul, "Anul morții lui Negru Vodă," Buletinul Comisiunii Monumentelor Istorice 1917-1923, 10-16, pp. 25-28.

12 See: N. Ghika-Budești, "Arhitectura Bisericii domnești. Origini și influențe," Buletinul Comisiunii Monumentelor Istorice 1917-1923, 10-16.

${ }^{13}$ See: I. Mihail: Pictura bisericii Domnești din Curtea-de-Argeș, Buletinul Comisiunii Monumentelor Istorice 1917-1923, 10-16. 
Bulletin hosted several vast monographs about the evolution of architecture in Moldavia and Wallachia written by Gheorghe Balș ${ }^{14}$ and Nicolae Ghika-Budești ${ }^{15}$, respectively.

It was not just the Bulletin that contained significant studies. Various publishing houses printed books that represented the remarkable work of important authors, such as the one written by Petre Constantinescu-Iași on the evolution of architecture in Moldovia ${ }^{16}$ and the one about the Originality of the open Porch in Romanian Architecture, ${ }_{17}^{17}$ those signed by I.D. Ștefănescu about the Moldavian painting ${ }^{18}$ or Nicolae Iorga's about the minor arts in Romania. ${ }^{19}$ Nicolae Iorga and Gheorghe Bals published together a history of old Romanian art, ${ }^{20}$ which represents the first attempt at a general and comprehensive view of the subject.

The works published during this period explicitly expressed that their goal was that of understanding and spreading knowledge about monuments and objects of old Romanian art and its historical evolution. However, a closer look at these texts can reveal more intimate thoughts, opinions and value judgements formulated by those who wrote them, illustrating the beliefs and aspirations of a generation and of an era.

For instance, the works of Gheorghe Balș and Nicolae Ghika-Budești about the architecture in Moldavia and Wallachia, respectively, are mono-

14 See: G. Balș, "Bisericile lui Ștefan cel Mare," Buletinul Comisiunii Monumentelor Istorice 1925, 18(43-46); idem, "Bisericile și mănăstirile moldovenești din veacul al XVIlea (1527-1582)," Buletinul Comisiunii Monumentelor Istorice 1928, 21.

15 See: N. Ghika-Budești, "Evoluția arhitecturii în Muntenia," Buletinul Comisiunii Monumentelor Istorice 1927, 20(53-54); idem, "Evoluția arhitecturii în Muntenia și Oltenia. II. Vechiul stil românesc din veacul al XVI-lea. De la Neagoe Basarab până la sfârșitul veacului," Buletinul Comisiunii Monumentelor Istorice 1930, 23; idem, "Evoluția arhitecturii în Muntenia și Oltenia. III. Veacul al XVII-lea. Epoca de tranziție: Domnia lui Matei Basarab," Buletinul Comisiunii Monumentelor Istorice 1932, 25(71-74); idem, "Evoluția arhitecturii în Muntenia și Oltenia. IV. Noul stil românesc din veacul al XVIII-lea," Buletinul Comisiunii Monumentelor Istorice 1936, 29(87-90).

16 See: P. Constantinescu-Iași, Evoluția stilului moldovinesc, Iași 1927.

17 See: P. Constantinescu-Iași, Originalitatea pridvorului deschis în arhitectura românească, Iași 1927.

18 See: I. D. Ștefănescu, L'évolution de la peinture religieuse en Bucovine et en Moldavie depuis les origines jusqu'au XIXe siècle, Paris 1928; idem, L'évolution de la peinture religieuse en Bucovine et en Moldavie depuis les origines jusqu'au XIX siècle. Nouvelles recherches. Ètude iconographique, Paris 1929.

19 See: N. Iorga, Les arts mineurs en Roumanie, Bucarest 1934, 1, 1936, 2.

20 See: N. Iorga, G. Balș, Histoire de l'art Roumain anciènne. L'art roumain du XIVé au XIXe siècle: description et documentation historique, Paris 1922. 
graphs about the evolution of architecture in the two countries and are based primarily on the review of all monuments found there or, at least, of the most important ones. Gheorghe Bals (1868-1934), engineer and art historian, member of the Romanian Academy, published two very important works in the Commission's Bulletin. The first is about the Churches of Stephen the Great (i.e. Stephen III of Moldavia), while the second presents Moldavian Churches and Monasteries in the $16^{\text {th }}$ Century being a continuation of the first. The two texts review all the known monuments from this timespan, the author's choice of that particular period was motivated by his belief that it was in these two stages that Moldavian art shaped its particular character, separating itself from the other territories which followed the Byzantine tradition. Although focused on architecture, the two texts also integrate other forms of art that were directly subordinated by architecture, such as painting and decoration.

The Evolution of Architecture in Wallachia (Evoluția arhitecturii în Muntenia) was investigated by Nicolae Ghika-Budești (1869-1943), architect, honorary member of the Romanian Academy, and member of the Commission for Historical Monuments, specialist in Wallachia's architecture and the author of numerous studies. This work, also published in the Commission's Bulletin, is a significant achievement. It reviews the most important churches in Wallachia and Oltenia, from the oldest monuments until the beginning of the $19^{\text {th }}$ century, focusing strictly on architecture. It is to a lesser extent a historical study, being mostly an investigation aimed at identifying the main church types and their stylistic evolution. This research is concentrated almost exclusively on the study of architectural forms, while written sources are left aside and, when used, it is only indirectly, for chronological purposes. In fact, the separation into successive periods is made based on formal aspects of the monuments although, at times, the country's political history is overlapped.

This brief presentation of the works of the two authors shows that their final purpose was that of depicting the evolution of architecture in the two countries. This evolution is seen as cyclical with an initial period of birth, followed by a time when forms crystallised, then flourished and, in the end, a time of decay. The central point of these writings is, in fact, to outline the ways in which a local style was shaped in these two countries, by analysing the influences received and assimilated.

The two authors identified two types of influences: those coming from the West and those from the Byzantine world. The authors believed these influences had superimposed a more ancient, local background, which disappeared, but none of the authors offered any proof for their hypothesis. Ul- 
timately, what Gheorghe Bals and Nicolae Ghika-Budești wanted to demonstrate was that the architecture of Moldavia and Wallachia were born from the confluence of forms coming from both the east and the west, but later freed themselves from these influences coming from afar and, thus, two local original styles were created. ${ }^{21}$ Eventually, these local styles died out, because of the pervasiveness of contemporary western styles at the end of the $18^{\text {th }}$ century and the beginning of the next.

To a certain extent, similar conclusions were formulated by the art historian Ion D. Ștefănescu (1886-1981) in his two-volume study about old painting in Moldavia and Bukovina from the earliest examples until the $19^{\text {th }}$ century, when traditional painting was pushed aside by western styles. In his works, he did not focus only on mural paintings, as most authors had, but also looked at illuminated manuscripts and works of decorative arts, because he believed that within an ecclesiastic complex, all works of art were created under the supervision of a single person who conducted the construction work, and who also had in mind the decoration of the compound, and cared for its endowment with all the necessary inventory.

Together, the two volumes constitute a comprehensive monograph. The author hoped to give a complete picture of the pictorial patrimony in Moldavia and Bukovina and, at the same time, to decipher the ways in which painting evolved in these areas. The author pointed out that the greatest problem he faced was that of elaborating a chronology, since the object of his research was to study the evolution of painting. This is another reason for including minor arts in his investigation, because these could offer more clues for dating different murals. Ștefănescu's methodology brings him near French positivism and the Viennese school of art history. In fact, the only foreign authors mentioned by Ștefănescu in the text's introduction are Charles Diehl, Henri Focillon and Josef Strzygowski. The structure of this study is very telling, since it is very similar to the work about Romanian wooden architecture by Coriolan Petranu ${ }^{22}$ and the one published by Virgil Vătășianu about Romanian stone churches from Hunedoara County. ${ }^{23}$ Both these students of the Viennese school explicitly mention that their works were made following Strzygowski's method. ${ }^{24}$ The structure is rather rigid and repeti-

${ }^{21}$ N. Ghika-Budești, "Evoluția arhitecturii în Muntenia," Buletinul Comisiunii Monumentelor Istorice 1927, 20(53-54), p. 8 (124).

22 See: C. Petranu, Bisericile de lemn din județul Arad, Sibiu 1927; idem, Monumentele istorice ale județului Bihor. I. Bisericile de lemn, Sibiu 1931.

${ }^{23}$ See: V. Vătășianu, Vechile biserici de piatră din județul Hunedoara, Cluj 1930.

${ }^{24}$ Ibidem, p. VI; C. Petranu, "Învățământul istoriei artelor la universitatea din Cluj," Vieața nouă 1924, p. 37. 
tions are unavoidable, as each work of art is analysed from a different point of view, following an interpretative scheme made of three parts. ${ }^{25}$

Ion D. Ștefănescu's conclusions are not very different from those formulated by Gheorghe Balș and Nicolae Ghika-Budești, depicting an original Moldavian art that developed separately and in parallel with that of its neighbours, born out of foreign influences from afar, which matured and crystallised by shedding them, and disappearing by giving way to new western styles. In his research, Ștefănescu began by formulating the hypothesis that the art of Moldavia and Bukovina, which flourished between the $14^{\text {th }}$ and the $17^{\text {th }}$ centuries, is original and not influenced by its neighbours. The way in which he conducted the investigation makes it seem as though Ștefănescu was interested in demonstrating this hypothesis and not necessarily in confronting it, and this transforms it, inevitably, into a thesis.

By doing so, he is not different from other Romanian art historians who were active between the two world wars, such as George Oprescu, Coriolan Petranu, Nicolae Iorga or Virgil Vătășianu. ${ }^{26}$ All of these scholars were also professors in various universities in Romania, as was Ion D. Ștefănescu himself, who, after studying in France, was invited to teach in Greece, France and Belgium, and after returning to Romania was employed as a professor at the universities of Iași, Cernăuți and Bucharest. Some of the above-mentioned authors explicitly affirmed that their aim was that of demonstrating the originality of Romanian art and placing it apart from that of other national arts of Europe. In this respect, Ion D. Ștefănescu circumscribes himself in the paradigm of Romanian culture, in general, and of art historiography, in particular. Defining national specificity was an important part of Romanian culture, and Romanians acutely felt the need to become a strong and respected nation, a peer of the others in Europe. Many hoped that through such scholarly ap-

25 This scheme is based on the one described in J. Strzygowski, Kunde, Wesen, Entwicklung, Wien 1922. Petranu names the three parts a)"cunoştința"(knowledge/Kunde), which is the stage of gathering and the critique of sources, b) "esența" (essence/Wesen) and "dezvoltarea artistică" (artistic development/Entwicklung) in C. Petranu, "Învățământul istoriei artelor la universitatea din Cluj," Vieața nouă 1924, pp. 35-37. Vătăşianu names the three parts corresponding to the same concepts appropriated from Strzygowski: (a) "monumentele" (the monuments), (b) "ființa (valorile tehnice şi artistice)" (the existence or being (technical and artistic values)) and (c) "evoluția" (the evolution) in V. Vătășianu, Vechile biserici de piatră din județul Hunedoara, Cluj 1930, p. VI.

26 V. Țoca, Art Historical Discourse in Romania, Budapest 2011, pp. 103-109; 43-54; 18-20; idem, "Old Romanian Art in Virgil Vătășianu's Works Between the Two World Wars and His Choice of Method," Studia Universitatis Babeș-Bolyai, Series Historia Artium 2012, 57(57/1), pp. 113-124. 
proaches, which aimed at being objective they could attain this status and, at the same time, put a halt to those unfriendly claims coming from abroad. Ion D. Ștefănescu seemed to be less interested in this last aspect. For sure, he wanted to elaborate a scholarly and correct work, despite demonstrating the thesis of Moldavian art's originality. At the same time, he wrote in the introduction to his work that he believed it was necessary to disseminate knowledge about old Moldavian art, both abroad and at home, specifically addressing the younger generation. However, despite this, Ion D. Ștefănescu did not elaborate conclusions based on his research, although his good faith can be grasped when taking a closer look at this final part of the text. It has been mentioned above that the author stressed Moldavian art's originality with respect to that of its orthodox neighbours from near or far, and its lineage from the Byzantine tradition. This means all neighbours, and this can be surprising, since this includes Wallachia. This detail is important because it is different from what many authors tried to demonstrate in the interwar period, that is, the unity of Romanian art throughout all the national territories. This conclusion is the result of research and observations and was assumed by the author, despite its political liability. What is quite different is the way in which the author reaches another conclusion. Stating that there is a strong relation between the old religious art of Moldavia and the later peasant art of the region. He did not support this assertion by any evidence and there is no demonstration throughout the text to sustain such an affirmation, rather it is the author's own opinion of the matter. It is striking to see how this thesis is placed in Ion D. Ștefănescu's text with such a lack of demonstration. This idea was also discussed by Nicolae Iorga, Gheorghe Bals and Nicolae Ghika-Budești, with the same blatant lack of arguments. It is true that Ștefănescu mentioned that further research must be done into this topic, but the way in which he presented the whole matter makes it look rather like a proven fact and not a hypothesis.

In 1922 Nicolae Iorga and Gheorghe Balș published the first work that was meant to offer a broad overview of Romanian old art in general and did so in French, in in a large format book, on glossy paper. The purpose of this writing printed in exquisite graphic conditions was, as is announced in the foreword, that of presenting Romanian art to the world, that is, the West. Even though the title is Histoire de l'art Roumaine ancièn and although it was published after the war, it does not include Transylvania. There is no mention of the reason for this omission in the text, but it can be assumed that this is due to the lack of information on the subject at the time for scholars coming from the old kingdom of Romania, and also to the fact that the text was mostly written before the war, when Transylvania was not part of the Romanian kingdom. 
As a matter of fact, information about this territory was included only at a later stage and only gradually. This was one of the reasons why Transylvanian art historians felt it was their duty to write almost exclusively about the art of their native land.

The part written by Gheorghe Bals is an extended abstract of his studies published in the Commission's Bulletin and it strictly presents the art of Moldavia. The one written by Nicolae Iorga, placed at the volume's beginning, discusses both Wallachia and Moldavia and is, as the subtitle suggests, a description of monuments and their historical presentation. In the foreword, Iorga warns that his part of the text is mostly a historical presentation of Romanian art. To a great extent his part of the book reflects the author's ideas about Romanian history through monuments, from the beginning of the $14^{\text {th }}$ century onwards, this being the moment the two Romanian principalities were founded. This is not surprising, since Nicolae Iorga (1871-1940) was first and foremost a historian, one of the most influential and prolific of the first half of the $20^{\text {th }}$ century. He was a professor at the University of Bucharest, member of the Romanian Academy, director of the Commission for Historical Monuments, and an active politician serving as minister and prime minister.

The main idea, which constitutes the backbone of Iorga's text, is that Romanian art originated in the art of the rural communities and was later taken over by princes and the aristocracy. ${ }^{27}$ Iorga also shared the view that Romanian medieval art was the melting pot of influences coming from both the east and the west, but he believed that these forms superposed a much older heritage, coming from time immemorial, passed on from the ancient Thracians. It is from this layering of influences that a truly national art was born. Iorga believed that peasants' art was taken over by the upper layers of society. In a famous example, he explained how the princely court at Curtea de Argeș was built like a peasant's house with an open gallery resembling a wooden porch and rooms running along it, because it was his belief that, at that moment in history, the prince was merely a peasant of a higher status. This theory was dismantled only a few years later by Nicolae Ghika-Budești, who demonstrated that these houses were built by western masons following the laws of Romanesque and early Gothic architecture. ${ }^{28}$ Iorga also wanted to demonstrate that the exonarthex in Moldavian churches in the time of Stephen III were also borrowed from vernacular architecture. The same structure and the same ideas can be found in another of Iorga's works about old Romanian art,

\footnotetext{
${ }^{27}$ Iorga, Balș, Histoire de l'art..., p. 9.

${ }^{28}$ Ghika-Budești, "Evoluția arhitecturii... I," p. 29.
} 
the one about what he calls minor arts. ${ }^{29}$ In this small book, as in the one mentioned before, the author follows a chronology that does not reflect the evolution of art, but that of political history, with which the historian was more familiar. Without offering any solid evidence, he pointed to the contribution of local artists of humble origin in the development of the art of icons, which, in his opinion, in the $18^{\text {th }}$ century becomes a national art. He believed that Byzantine models had been adopted by local ecclesiastic workshops, but also by peasant craftsmen, who made icon painting part of their culture. This last idea, although hazily expressed, can be found in I.D. Ștefănescu's work. ${ }^{30}$

Petre Constantinescu-Iași (1892-1977) also discussed the Evolution of the Moldavian Style (Evoluția stilului moldovinesc), pointing out that the medieval principality had its own original architecture. ${ }^{31}$ The author planned this to be a comprehensive study, since he believed that until that moment a substantial number of works had been written on the subject. The book is based on these last, but also on the scholar's own research. He believed that the official Moldavian medieval art was religious and that churches were its most significant achievements and asserted that until its demise at the beginning of the $19^{\text {th }}$ century, it had undergone continuous evolution. It is an important study, because it systematised the works published in the last several decades. Petre Constantinescu-Iassi's personal contribution is that of following the evolution of architecture in accordance with changes in the structure of porches. These last also constituted the subject of a large study about the originality of Moldavian church porches (Originalitatea pridvorului deschis în arhitectura românească) in which he aimed to demonstrate that a particular form of architecture developed in this area, as well as of other works where he compared the Moldavian art to that of the Byzantine world and to that of neighbouring Wallachia. ${ }^{32}$

It is worth noting Petre Constantinescu-Iași's interest in demonstrating the originality of Moldavian art, while stressing its close relationship with the art of its north-eastern orthodox neighbours, and it is a fair guess that it is, to a great extent, politically motivated. ${ }^{33}$ He was a founding member, later a very active one, of the Romanian Communist Party, an organisation which lobbied during the interwar period for the disintegration of Romania in order to free

${ }^{29}$ A.-M. Musicescu, "Nicolae Iorga și studiul artelor în România," Studii și cercetări de istoria artei. Seria arta plastică 1966, 13(1), pp. 16-17.

30 I. D. Ștefănescu, L'évolution de la peinture religieuse en Bucovine et en Moldavie depuis les origines jusqu'au XIX ${ }^{e}$ siècle, Paris 1928, pp. 303-304.

${ }^{31}$ See: P. Constantinescu-Iași, Evoluția stilului moldovinesc, Iași 1927.

32 See: P. Constantinescu-Iași, Originalitatea pridvorului deschis în arhitectura românească, Iași: Viața romînească, 1927.

33 Țoca, Art Historical Discourse..., pp. 28-29. 
the oppressed minorities. ${ }^{34}$ Another interesting observation to be made is that almost none of the major authors of the period quote him, although his works were published in 1927, and they quote other works from that year.

In Transylvania, art historical writings by Romanians had a marginal character until after World War I. In the interwar period, the most significant contributions in the field of old Romanian art were those authored by Coriolan Petranu and Virgil Vătășianu.

Coriolan Petranu (1893-1945) has a special place in Romanian art historiography in between the two world wars, because his writings were dedicated almost exclusively to the art of Transylvania, and most of all to that of the Romanians there. He believed their art represented a complex whole made up of high art and peasants' art. ${ }^{35} \mathrm{He}$ was among the first Romanian scholars to study art history at a western university, and he was the first professor of art history at the newly founded Romanian university in Cluj. His apprenticeship in Vienna under Josef Strzygowski marked his methodological approaches. Petranu was an art historian with an agenda, who dedicated his entire activity to the study of Transylvanian art and to the spread of the results of his research, both at home and abroad.

He often polemicized with art historians from other countries, especially from Hungary on various aspects of Transylvanian art, often in heated written debates which sometimes went beyond what was acceptable for academic discourse. In his view, the objectives of a Romanian art historian in Transylvania should be to study its art, elaborating inventories of the monuments and works of art there, and then writing monographs about them, and all of this done with the final purpose of writing comprehensive texts about the art and architecture of the region based on those monographs. ${ }^{36}$

Petranu based his methodology on those described by Hans Tietze and Josef Strzygowski, in line with the philological-historical methods of positivism, based on documents. According to these authors, in the case of art histo-

${ }^{34}$ D. C. Giurescu, Ce a fost Partidul Comunist Român, "Clipa," available online: <http://www.revistaclipa.com/2583/2009/12/repere-academice/ce-a-fost-partidul-comunist-roman $>$ [accessed: 15 May 2013].

35 C. Petranu, "L'art Roumain de Transylvanie," La Transylvanie 1938, p. 5; idem, "Die alte kirchliche Kunst der Rumänen," in: idem, Ars Transsilvaniae, Etudes d'histoire de l'art transilvain. Studien zur Kunstgeschichte Siebenbürgens, Sibiu 1944, p. 144.

${ }^{36}$ C. Petranu, "Rolul istoricului de artă român în Transilvania," Cronica Numismatică și arheologică 1923, 4, p. 11. 
ry, the most important document is the work of art itself, therefore the visual, formal and structural aspects, played the most important part in any investigation. He also appropriated Alois Riegl's concept of Kunstwollen, which was responsible for setting in motion the mechanism of creation, determined by conditions of environment, race and society. Coriolan Petranu's work strongly reflects the ideas of the Viennese school of art history, which he used in order to elaborate a history of Romanian art in Transylvania. By doing so he hoped to be as objective and scholarly as possible. The use of a methodology borrowed from the West represented, in his view, the guarantee for producing writings that would be correct and objective, which for him constituted the supreme goal. ${ }^{37}$

Many of Petranu's important works were included in Ars Transsilvani$a e^{38}$ a collection of works about Transylvanian art, not just of the Romanians, but also that of Hungarians and Saxons. Despite this, he did not see the art of this area as a whole, but as several national arts existing apart from one another in one territory. Although he referred to the art of the major ethnic groups of Transylvania, his main interest was the art of the Romanians in this area, which he believed was a unified entity made of two parts: high art and peasants' art. In the other important book of his, Romanian art in Transylvania (Arta românească din Transilvania), Coriolan Petranu wrote in the conclusion that the art of the Romanians in the region had the following characteristics: "1. oppressed character. 2. pendulating between the east and the west. 3. its popular [peasant] character. 4. artistic qualities." ${ }^{\prime \prime 9}$ These four points sum up the Transylvanian scholar's thesis regarding Romanian art, in general, and that of Transylvania, in particular. All these express the great importance Petranu attached to the art of the Romanians in the province, and also to the role it played in Europe and in the Balkans. He believed that in Transylvanian art, Romanians played a major role in shaping the art of the peasants, their art influencing also that of other nations, while the German Saxons played a leading role in shaping high art, whereas Hungarians, he believed, played only a minor part in both. This expresses his belief that Romanians had a superior civilisation, which although not producing high art, produced a valuable peasant art that was equal to that of any other nation in Europe. He was also a Germanophile throughout his life and always had

37 C. Petranu, "Învățământul istoriei artelor la universitatea din Cluj," Vieața nouă 1924, p. 37.

38 See C. Petranu, "Ars Transsilvaniae. Etudes d'histoire de l'art transilvain. Studien zur Kunstgeschichte Siebenbürgens," Sibiu 1944.

39 "1. caracterul de oprimare. 2. oscilarea între est și vest. 3. caracterul popular 4. calitățile artistice," in: C. Petranu, Arta românească din Transilvania, Sibiu 1943, p. 25. 
a favourable opinion about German achievements. As for Hungarians, he always saw them as the arch-enemy, and time and again stressed the dangers of Hungarian revisionism, while he tried to demonstrate that they were a people which did not have any contributions to European culture, since they had settled late in the region and all that they did was to borrow from others. He often pointed out that they were influenced by the Germans in the high art and by Romanians in their folk art. ${ }^{40}$

Therefore, he concentrated much of his research on investigating the art of Romanians in Transylvania, and most of all, on the study of wooden architecture, which he believed constituted their major contribution. His most important published research was about the wooden churches in $\mathrm{Arad}^{41}$ and Bihor ${ }^{42}$ counties, which are some of the first serious contributions by a Romanian scholar to the research of the art of Romanians in Transylvania. Petranu's effort of recording all the wooden monuments in the two counties is important in itself, because it documented a great number of monuments, many of which have since disappeared. The two books represent a scholarly work, as opposed to Ars Transsilvaniae and the aforementioned booklet about the art of Romanians in Transylvania. These last are filled with value judgements and personal opinions, as are many other texts meant for the general public or for a foreign audience, while in the two books about wooden architecture, he mostly refrained from any unscholarly comment.

Virgil Vătășianu (1902-1993) joined Petranu in his efforts to investigate Romanian art in Transylvania. He also studied in Vienna with Josef Strzygowski and received a doctoral degree there; he served three mandates as secretary of Accademia di Romania in Rome between 1930 and 1946. The most important book he published between the two world wars was about the stone churches of Hunedoara county (Vechile biserici de piatră românești din județul Hunedoara), ${ }^{43}$ which represents an extended version of his doctoral thesis. It was the result of field research he had conducted in the area and it represents a fundamental study of a subject poorly investigated at the time. The research method used in this book is based on that of Josef Strzygowski - who supervised his doctoral thesis -, just like Petranu's scholarly works. In this book, Vătășianu aimed to demonstrate that the church architecture of the Romanians in Hunedoara County was mostly based on the old autoch-

40 Ibidem, pp. 25-27.

${ }^{41}$ See: C. Petranu, Bisericile de lemn din județul Arad, Sibiu 1927.

42 See: C. Petranu, Monumentele istorice ale județului Bihor, 1: Bisericile de lemn, Sibiu 1931.

43 See: V. Vătășianu, "Vechile biserici de piatră din județul Hunedoara," Anuarul Comisiunii monumentelor istorice. Secțiunea pentru Transilvania 1929. 
thonous wooden architecture of north-eastern Europe, while influences coming from afar, from the west, were added. He believed that the stone churches in the region were based on wooden models which were typical of this area where East and West converge. This idea of the precedence of wooden architecture was appropriated from his professor in Vienna, who believed in the existence of a northern world separate from that of the Mediterranean. Vătășianu also demonstrated that masonry and mortar showed influences coming from this latter area, that is, the south of the continent.

Vătășianu tried to demonstrate this idea in several lesser known and often overlooked texts: three about the wooden and stone architecture in Moldavia ${ }^{44}$ and one about the Romanian liturgical textiles in the Byzantine tradition. ${ }^{45}$ In the first two studies, he discussed the relation existing between wooden and stone churches in Moldavia, aiming to demonstrate the same idea of the precedence of the former, and how early stone architecture is derived from much older wooden constructions. It must be noted that the reason why Vătășianu looked at this subject outside of Transylvania, in other territories inhabited by Romanians, was to show the unity existing between all the provinces of the contemporary Romanian state, in spite of the natural differences among its regions.

Both Petranu and Vătășianu appropriated and applied Strzygowski's ideas - who had been a professor for both - to the situation in Transylvania. They both investigated areas that had been largely ignored and wished to conduct research into the culture of their own people that would lead to it being better understood, both at home and abroad. Influenced by their professor in Vienna, the two scholars included the architecture of the Romanians in a larger area, namely that of Northern European wooden architecture, which they believed had no connection with the Mediterranean world, although the two Transylvanian scholars admitted influences coming from the south and east by way of Byzantium or the Slavic peoples. In their writings from this period, Strzygowski seems to be their supreme authority and his ideas were rarely questioned. They adopted his work methodology, saying it was the most complex, advanced and the only one which was worth using in the field of art history. This was because they believed it allowed a multifaceted investigation of the work of art. In reality, Petranu and Vătășianu opted for this

${ }^{44}$ See V. Vătășianu, "Pentru originea arhitecturii moldovenești," Junimea Literară 1927, 16; idem, "Bolțile moldovenești, originea și evoluția lor istorică," Anuarul Institutului de Istorie Națională 1929, 5; idem, "Contribuție la cunoașterea bisericilor de lemn din Moldova," in: Închinare lui N. Iorga cu prilejul împlinirii vârstei de 60 de ani, Cluj 1931.

45 See V. Vătășianu, L'arte bizantina in Romania. I ricami liturgici, Roma 1945. 
method, because it allowed them to conduct research based on a monument or a work of art, focused on the study of forms, and less on written sources. This ultimately led to a very subjective, speculative discourse, in line with the one practised by their Viennese master. They also developed the structure of their texts using the framework elaborated by Strzygowski based on the three points of view of a work of art: ${ }^{46}$ Kunde, Wesen, and Entwicklung. ${ }^{47}$ By using the Viennese scholar's methodology, they also appropriated his axioms. ${ }^{48}$

In the interwar period, the two Transylvanian art historians concentrated their research on Romanian art history in their native land, without, as Vătășianu later did, taking interest in the artistic production of the other nations living there. Although they did write every now and then about art in the modern period or about that of their time, their main interest was always the study of old Romanian art, mainly religious architecture. The two scholars strongly believed that it was their duty to study the art of Romanians from Transylvania, a subject previously overlooked, in a time when concerted attacks were staged against the newly enlarged Romanian state and when many questioned the equitableness of the territorial changes which followed the war.

They chose this path and appropriated Strzygowski's axioms, because it best served their purposes. They hoped to clearly demonstrate the strong bonds that had existed between all the Romanian national territories throughout the centuries, since time immemorial. Like their professor in Vienna, the two Romanian art historians were convinced of the precedence of wooden architecture and that it transmitted its forms to the later masonry architecture. They also sought to demonstrate that the wooden architecture created by Romanians was part of the larger area of Northern European tradition of wooden constructions, dating from ancient times, which was profoundly different from that of the Mediterranean area. In their writings, Petranu and Vătășianu aimed to demonstrate the originality and unity of Romanian art. These were very important aspects during the interwar period, because in this way, these Transylvanian art historians hoped to prove, by means of art historical research, the cultural unity, as well as the superior artistic qualities of the Romanians in all the territories they inhabited.

46 C. Petranu, Învățământul istoriei artelor la Universitatea din Cluj, București 1924, pp. 35-37; R. Born, "The Historiography of Art in Transylvania and the Vienna School in the Interwar Period," Centropa 2009, 9(3), p. 190.

47 See J. Strzygowski, Kunde, Wesen, Entwicklung. Ein Einführung, Wien 1922.

${ }^{48}$ C. Simon, Artă și identitate naţională în opera lui Virgil Vătăşianu, Cluj-Napoca 2002, p. 36. 
Like many art historians who studied in Vienna, and who were later active in important institutions of the successor states of the late empire, Petranu and Vătășianu felt it was their duty to put all their resources, energy, knowledge and scholarship into serving their country, the Romanian national state. ${ }^{49}$ Strzygowski's methodology came with a complex theoretical construction, which was readily taken over by the two Transylvanian art historians, because it offered them the precise instruments they needed in order to demonstrate their ideas and theses, and also because they believed this guaranteed the historical and scholarly honesty, and endowed their research with truth and impartiality. ${ }^{50}$

In the field of old Romanian art, interwar historiography made important advances with respect to the previous period. There was no consensus among the scholars of the time as to what art history meant or the methods to be used in studying and interpreting the subject being studied. But most art historians writing before the middle of the century shared several common ideas and ideals, and many of them tried to find an answer to the issue of national identity expressed through art. They based their research on strict and rigorous methods, which they believed would lead to the elaboration of truly scientific writings, their final aim was to achieve conclusive and definitive results, and, in this way, gain the respect of the international academic community. It is likely that except for Constantinescu-Iași, all other Romanian scholars were animated by sincere patriotism and a sense of civic duty. Like many of their contemporaries, they believed that intellectuals were called upon to research and to discover the hidden treasures of their country and to present them to people at home and to the outside world. This must be one of the reasons many of their works were published in foreign languages, and sometimes abroad. Despite this, most of these works were not meant to be propaganda, although some were financed, directly or indirectly, by the state for this purpose. The general intention was that of producing scholarly works meant for the use of specialists, useful, precise and objective, which would be reliable because of these qualities. It is true that some were, in part or entirely, destined for use by the general public, with the authors hoping that they would be useful to art and history lovers, as well as for educating a young generation of artists.

49 Bakoš, "From Universalism...," pp. 79 sqq, pp. 86 sqq.

50 See M. Rampley, "The Strzygowski school of Cluj. An episode in interwar Romanian Cultural policies," Journal of Art Historiography June 2013, 8, available online: < https:// arthistoriography.files.wordpress.com/2013/06/rampley.pdf>; V. Țoca, "Old Romanian Art in Virgil Vătășianu's Works Between the Two World Wars and His Choice of Method," Studia Universitatis Babeș-Bolyai, Series Historia Artium 2012, 57(1), pp. 113-124. 
Of all fields of Romanian art historiography, the last to develop was that of art made following western patterns in the $19^{\text {th }}$ and the first half of the $20^{\text {th }}$ century. This can be explained by the evolution of the subject itself. Old Romanian art had hitherto been predominantly religious and with western influences partially present. It was only at the beginning of the $19^{\text {th }}$ century that art in the Romanian territories began to take over the forms of western art and styles. In the second half of that century, this type of art was fully established, while the old Byzantine forms were abandoned even in the architecture and decoration of churches. Artists such as Theodor Aman and later, Nicolae Grigorescu, became very important figures, revered by their contemporaries, while many began talking about the birth of a national art. The works of Grigorescu in particular sparked the first discussions and debates about the role and aims of a national art. His works and personality have since become a benchmark which could hardly be avoided.

But since the beginning of the $20^{\text {th }}$ century, and mostly until World War I, writings about the more recent Romanian art was inconsistent. At the turn of the century, a number of biographies written mainly by important men of letters were published, of which most were dedicated to Nicolae Grigorescu, such as those written by Nicolae Petrașcu in 1895 and reprinted after the war, ${ }^{51}$ and by C.I. Istrate in 1908, while the most successful and popular were those written by Barbu Ștefănescu Delavrancea ${ }^{52}$ and, especially, Alexandru Vlahuță ${ }^{53}$. Art criticism became important, but this is not the object of the present study.

This evolution was interrupted by the war, but after 1919 cultural life in Romania began regaining its vitality. Around that time, the first books were published, periodicals were reissued, or new ones appeared, and exhibitions became more numerous. This is not to say there were no publications or exhibitions during the war, but these were made mostly to offer people a sense of normality in a world severely affected by the conflict, both under the patronage of the German occupants and the Romanian government in exile in Moldavia. However, this pre-war normality sought by most after the conclusion of hostilities was never found. A new generation with different aspirations and interests began to emerge. This course would be maintained until the establishment of the communist regime in 1947.

51 See: N. Petrașcu, Pictorul Grigorescu, București 1895.

52 See: B. Delavrancea, "Din viața lui Nicolae Grigorescu," Luceafărul 1905, 4(1).

53 See: A. Vlahuță, Pictorul N. I. Grigorescu, vieața și opera lui, București 1910; A. Vlahoutza, N. I. Grigorescu, sa vie et son śuvre, Bucarest 1911. 
In the first two decades of the century, texts about more recent Romanian art were relatively few, but their number increased rapidly after 1920 . The interest of authors was mostly turned towards the study of painting and painters, and less towards sculpture, while architecture was all but ignored. The preferred genres were biographies and artist monographs, the latter being written by both scholars and connoisseurs. Several catalogues raisonnés and collections of documents were published. There are no general works about the subject, but for two notable exceptions: George Oprescu's extensive studies about Romanian painting ${ }^{54}$ and the graphic arts $^{55}$ of the $19^{\text {th }}$ century. Art criticism and art theory were also very important in this period, the number of contributions being significant. There were even a few scholars and art historians who also wrote art criticism in the numerous cultural journals of the time. Many authors, in fact, visited various genres, and thus wrote works of uneven quality. This is true for both scholars and connoisseurs, and it is sometimes difficult to place some works in one category or another. In the case of some art historians that were employed by universities or other state institutions, there is great difference between the texts published under the auspices of their respective institution and those works that were privately commissioned.

I will not discuss here the contributions of the connoisseurs or others who wrote about the subject. I will instead take a closer look at George Oprescu's work on Romanian art of the $19^{\text {th }}$ and the $20^{\text {th }}$ centuries.

In the historiography of the Romanian art of the $19^{\text {th }}$ and the $20^{\text {th }}$ centuries, the works of George Oprescu (1881-1969) hold a very important position. He authored numerous studies and books, he was a professor at the universities in Cluj and Bucharest, an art critic, initiated collective research projects in the field of Romanian art, founded the Analecta review and formed a generation of young art historians, some of whom began to be active between the wars. He served as a museum director, as a member of the Commission for Historical Monuments, and as secretary for the League of Nation's International Committee on Intellectual Cooperation, among other positions. ${ }^{56}$

During this period, he wrote over fifty books, catalogues and university syllabuses, as well as hundreds of scholarly papers, press articles and pages of

${ }^{54}$ See G. Oprescu, Pictura românească în secolul al XIX-lea², București 1943.

55 See G. Oprescu, Grafica românească în secolul al XIX-lea, vol. 1, București 1942, vol. 2, București 1945.

56 Omagiu lui George Oprescu cu prilejul împlinirii a 80 de ani, eds. T. Vianu, M. Popescu, București 1961, p. XXV. 
art criticism. ${ }^{57}$ Oprescu's research covers a wide range of topics, from studies about the Romanian art of the $19^{\text {th }}$ and $20^{\text {th }}$ centuries to European art or Romanian folk art. Such a volume of works is impressive, but, as in the case of Iorga's opus, Oprescu's works are not only different in character and scope, but also largely vary in terms of their value and scholarship. This is especially true when considering his works on the Romanian art of the $19^{\text {th }}$ and the $20^{\text {th }}$ centuries.

George Oprescu was a remarkable figure in Romanian academic and cultural circles between the two world wars and in the decades that followed. He studied letters and comparative literature, and this broadened his view, leading him to use a distinct methodology, very different from that of most art historians of his generation. He was criticised by many, at times vigorously, mainly by the Transylvanians, who never failed to point out that he was not a real art historian, because he had no formal training in the field of art history. The differences between him and other art historians are evident and unmistakable but, in retrospect, they all have more in common than it would appear at first glance. There are many things he shared with Coriolan Petranu. They had common ideals; they acted in similar ways on the public scene and also had many things in common in terms of the methodology they used in their scholarly works. Both were strong believers in the role an art historian must play in society, working in cultural institutions, and shared similar views regarding the role the state should play in creating those institutions that were absent, while working to support and develop those that already existed ${ }^{58}$ Like his colleague from Cluj, who published an extensive study about museums in Transylvania, ${ }^{59}$ Oprescu was also interested in museums, many of his efforts being pointed in that direction. But teaching was the one activity he dedicated most of his energy to, preferring it to research, therefore syllabuses, printed or lithographed, represent an important share of his writing. Finally, both strongly believed in the originality and great universal value of Romanian art and this belief guided most of their activity. Like Petranu, Oprescu initiated channels of communication with universities, art history institutes and libraries abroad, mostly in the west, published papers about Romanian high and folk art in foreign languages that were meant

${ }^{57}$ For George Oprescu's complete bibliography see: "Bibliografia lucrărilor Acad. Prof. G. Oprescu," in: Omagiu lui George Oprescu cu prilejul împlinirii a 80 de ani, eds. T. Vianu, M. Popescu, București 1961.

${ }_{58}$ M. Popescu, "Cuvînt înainte," in: G. Oprescu, Pictura românească în secolul al XIXlea, București 1984, p. 8.

59 See C. Petranu, Muzeele din Transilvania, Banat, Crișana și Maramureș. Trecutul, prezentul și administrarea lor, București 1922. 
to be distributed abroad, and was very affected by the negative propaganda of some foreign authors directed against Romania, its art and culture. This same type of patriotic dedication guided them in their academic mission, towards their final goal. They believed that an art historian must play an active role in society, in order to contribute to disseminating culture and the love of the homeland, which would shape a positive image of Romania and its cultural heritage. Oprescu's articles published in contemporary newspapers and magazines reveal what his beliefs were, because he did not express them openly in his other writings. In the interwar period, those ideas were shared by many intellectuals, who believed that culture could and should contribute in a decisive fashion to the nation's prestige and well-being. In these writings, Oprescu mentioned time and again the chief role that should be assumed by "institutions of public education" ("schools of all degrees, research institutes, museums, libraries, theatres;" "theatres, public book collections, museums, cultural and research institutions;" "schools, libraries, museums, theatres," these institutions are mentioned repeatedly in his writings). ${ }^{60}$

George Oprescu's book about Romanian painting in the $19^{\text {th }}$ century (Pictura românească în secolul al XIX-lea) was the result of teamwork he coordinated among students and assistants from the art history seminar of the University of Bucharest. The goal of this team was to create a general comprehensive work about Romanian art after 1800, which would serve as a syllabus for students, but was also intended for use by specialists or art lovers.

Although Oprescu was aware that there were desperately few published studies and monographs and that it was difficult to write a general history of Romanian art in their absence, he believed in the necessity of such a work for use by students and the general public. The book is actually a much-enlarged version of the one printed in Malmö in 1935 in three separate versions, French, English and Swedish. ${ }^{61}$ This is an example of the effort made by Romanians to disseminate knowledge abroad about the art and culture of their country. This was mirrored by the publishing of his book about Romanian folk art in French and English. ${ }^{62}$ Oprescu was an admirer of Romanian peasant art, an

${ }^{60}$ G. Oprescu, Anul artistic la noi și la alții. Studii și impresii, București 1934, pp. 41-42; V. Țoca, "George Oprescu. Activitatea și crezurile sale în perioada interbelică," in: Istoria Culturii. Cultura istoriei. Omagiu Profesorului Doru Radosav la vârsta de 60 de ani, eds. I. Costea, O. Ghitta, V. Orga, I. Pop, Cluj-Napoca 2010, pp. 437-447.

${ }^{61}$ See G. Oprescu, L'art roumain de 1800 à nos jours, Malmö 1935; idem, Roumanian Art from 1800 to Our Days, Malmö 1935; idem, Samtida Konst i Romänien. Ett urval bilder med inledande text, Malmö 1935.

${ }^{62}$ See G. Oprescu, L'art du paysan roumain. Avec une preface de Henri Focillon, Bucarest 1937; idem, Peasant Art in Rumania. With a foreword by Henri Focillon, Bucharest 1940. 
avid collector, and wrote one of the first books on this subject. This book was translated into and published in foreign languages by the Romanian Academy. ${ }^{63}$ This was followed, in 1940, by a lithographed syllabus for the students studying at the university in Bucharest. The title of the collection in French is telling in terms of the author's and the publisher's objectives: "Connaissance de l'âme et de la pensée roumains". In these books, Oprescu presented the history of painting made in the Western manner in Romania after 1800 and related it to what was going on in the West, mostly in France. By doing so, he described the country's modernisation and synchronisation with Europe following its art.

Of the books published by Oprescu in the interwar period, only those about Nicolae Grigorescu, ${ }^{64}$ Ion Andreescu ${ }^{65}$ and Nicolae Petrașcu ${ }^{66}$ can be considered true monographs. The others, published in various art series, about Jean Al. Steriadi, ${ }^{67}$ Camil Ressu ${ }^{68}{ }^{6}$ Stefan Popescu ${ }^{69}$ or Eustațiu Stoenescu ${ }^{70}$ are texts of a different nature, often excessively praising the artists, many of whom were the author's personal friends. The latter are not monographs of an artist, but essays which eulogise the artist.

Apart from the general texts mentioned above about the Romanian painting and graphic arts of the $19^{\text {th }}$ century, Oprescu also wrote one about the painting after Ștefan Luchian, that is, after the turn of the century. This was only lithographed, and later abridged and made into a catalogue for an exhibition of Romanian art in Bern. ${ }^{71}$ These texts were meant to complement and to be a continuation of those written by Nicolae Iorga, Gheorghe Balș and Petre Constantinescu-Iași about old Romanian art. Of these, the most ambitious is the one dedicated to Romanian painting in the $19^{\text {th }}$ century. This book is, through its structure, references, list of illustrations and bibliography, the most scholarly and rigorous. When he began this vast study, Oprescu had in mind filling a gap in Romanian art historiography. Although he is credited as the single author, the work is actually the result of teamwork done by his students and collaborators at the university. ${ }^{72}$

\footnotetext{
${ }^{63}$ See G. Oprescu, Arta țărănească la români, București 1922.

${ }^{64}$ See G. Oprescu, Grigorescu desinator, București 1941.

${ }^{65}$ See G. Oprescu, Andreescu, Craiova 1931.

66 See G. Oprescu, G. Petrașcu, Craiova 1931; idem, G. Petrașcu, București 1940.

67 See G. Oprescu, Jean Al. Steriadi, București 1942.

${ }^{68}$ See G. Oprescu, Camil Ressu, București 1942.

69 See G. Oprescu, Ștefan Popescu, București 1942.

70 See G. Oprescu, Stoenescu, București 1946.

${ }^{71}$ See G. Oprescu, La peinture roumaine contemporaine, Berne 1944.

72 G. Oprescu, Pictura românească în secolul al XIX-lea², București 1943, p. 6.
} 
Many of them also published several monographs and monographic studies, in the period between the two editions. The second edition (1943) is the most complete and includes the results of the above-mentioned works by Oprescu's students and collaborators, but he also used other works, mostly published in between the two world wars, and written by other researchers in the country. ${ }^{73}$ The aim of this project was to produce a work that would have a definitive result, although Oprescu was aware that it was not possible at that stage of his research. He was confident that his work, based on primary visual and written sources, would eventually produce the desired result, and that what had been once written could be changed only by addition and not by revision. ${ }^{74}$ It is harder than in the case of Petranu, for instance, who explicitly defines his methodology, to describe Oprescu's method. It is inspired by several western scholars' work, such as Alois Riegl, Wilhelm Worringer or Theodor Lipps. We also know he admired Josef Strzygowski and Henri Focillon. All these art historians were presented in Analecta, the review he coordinated, and he borrowed a little from each of them. Although Oprescu based his investigation on both written and visual sources, he usually tended to focus on the works of art he analysed in a descriptive manner, refraining from being speculative.

In Oprescu's book, the entire evolution of Romanian painting is constructed in relation to the evolution of art in the west, and the investigation only considers those artists who adopted a western manner of painting. Indirectly, painting in the Byzantine style is seen as representing the past, while that produced in a western manner is associated with modernity and nation-building. Like Petranu and others, Oprescu expressed his regret for the fact that the Byzantine way had been abandoned in religious painting, as it represented a tradition associated with centuries-old Romanian spirituality, but agreed that it was an unavoidable side effect of modernising the country.

Another aspect worth noticing about the contents of this book is that although it was published more than two decades after the war ended, Transylvania is mostly overlooked, especially in the first part of the book, while Bessarabia is completely ignored. The few painters from Transylvania mentioned in the book are almost all ethnic Romanians and are introduced in the text only if they had been active in the old kingdom of Romania. In the second part of the book, there is a subchapter of a mere seven pages dedicated to the art centres in Transylvania and the Banat, which is essentially a compilation

\footnotetext{
${ }^{73}$ Ibidem, p. 5.

${ }^{74}$ Ibidem, p. 6.
} 
based on monographs and other texts written by authors native to these provinces. This is similar to what Nicolae Iorga and Gheorghe Balș did in their general presentation of old Romanian art.

Books about the general history of art in Romania produced between the two world wars fall into two categories. First, there are those that result from comprehensive research of a period or of a region, and secondly, there are those meant for the general public at home or abroad. Regardless of the chosen genre, the methodology used or the intended reader, these are written in such a way as to match the standards of similar works produced in the West. In these books, the authors mostly refrained from openly polemicizing, introducing value judgements or going off topic. However, this was not always the case. In several instances, the echoes of the Great Debate are present, woven into the tissue of the texts.

The authors we reviewed are professional art historians and they strived to produce works of a high value. They believed that by conducting objective research and writing books, Romanian art and culture could be presented in a positive light to specialists and the general public in an unbiased and truthful way. The final purpose was to demonstrate that Romania had an art and culture that were of equal quality and importance to those of any other nation on the continent, and this placed her within the larger European family. At the same time, the aim of such a narrative was to demonstrate the cultural unity of all the territories incorporated in the greater Romanian state in the wake of World War I.

This task was assumed by many of those active during that period, as Romanian state civil servants or as citizens. This is an attitude that can be seen in many texts, but with an emphasis in those books which were written in foreign languages and addressed to the western public, and produced by scholars employed by the state or whose work was financed by state money. Although all fields of art were approached in order to achieve this goal, the most important and consistent works were in the field of old Romanian art.

National specificity was also a topic which interested many authors. This seems to have been the purpose of works about the art of the last two centuries, whose aim is to demonstrate the synchronisation with European contemporary tendencies. The ultimate goal is the same, namely that of proving that Romanian art is part of European art.

Indirectly, the appropriation of research methods used in the West tells the same story. Romanian art historians used these instruments in the hope of having a guaranteed way of producing works that were of a high quality, 
objective and credible. The models are mostly those of French positivism and of the Viennese school of art history, which were held in high esteem. Romanian authors appropriated these methods and used them to serve their own purposes, seeking to demonstrate their own theses and ideas.

What seems to have motivated most art historians was a sincere and profound civic and patriotic duty, actively assumed by the authors. This duty was that of defending the Romanian national state, the existence of which seemed to be the only thing all Romanians, with the aforementioned exceptions, agreed on during the two world wars.

\section{BIBLIOGRAPHY}

* * *, "Cuvinte începătoare," Buletinul Comisiunii Monumentelor Istorice 1908, 1

Bakoš J., "From Universalism to Nationalism. Transformation of Vienna School Ideas in Central Europe," in: Die Kunsthistoriographien in Ostmitteleuropa und der nationale Diskurs, eds. R. Born, A. Janatková, A. S. Labuda, Berlin 2004

Balş Gh., O vizită la câteva biserici din Serbia, Bucureşti 1911

Balş Gh., "Notiță despre arhitectura Sfântului Munte," Buletinul Comisiunii Monumentelor Istorice 1913, 6

Balș Gh., "Bisericile lui Ștefan cel Mare," Buletinul Comisiunii Monumentelor Istorice $1925,18(43-46)$

Balş Gh., "Bisericile şi mănăstirile moldovenești din veacul al XVI-lea (1527-1582)," Buletinul Comisiunii Monumentelor Istorice 1928, 21

Born R., "The Historiography of Art in Transylvania and the Vienna School in the Interwar Period," Centropa 2009, 9(3)

Constantinescu-Iaşi P., Evoluția stilului moldovinesc, Iaşi 1927

Constantinescu-Iaşi P., Originalitatea pridvorului deschis în arhitectura românească, Iași 1927

Drăghiceanu V., "Curtea domnească din Curtea de Argeş. Note istorice şi arheologice," Buletinul Comisiunii Monumentelor Istorice 1917-1923, 10-16

Ghika-Budeşti N., "Arhitectura Bisericii domnești. Origini şi influențe," Buletinul Comisiunii Monumentelor Istorice 1917-1923, 10-16

Ghika-Budeşti N., "Evoluția arhitecturii în Muntenia. I.," Buletinul Comisiunii Monumentelor Istorice 1927, 20(53-57)

Ghika-Budeşti N., "Evoluția arhitecturii în Muntenia şi Oltenia. II. Vechiul stil românesc din veacul al XVI-lea. De la Neagoe Basarab până la sfârşitul veacului," Buletinul Comisiunii Monumentelor Istorice 1930, 23

Ghika-Budeşti N., "Evoluția arhitecturii în Muntenia şi Oltenia. III. Veacul al XVII-lea. Epoca de tranziție: Domnia lui Matei Basarab," Buletinul Comisiunii Monumentelor Istorice 1932, 25(71-74)

Ghika-Budeşti N., "Evoluția arhitecturii în Muntenia şi Oltenia. IV. Noul stil românesc din vecul al XVIII-lea," Buletinul Comisiunii Monumentelor Istorice 1936, 29(87-90) 
Ghika-Budeşti N., Gh. Balş, "Ruinele bizantine din Mesembria," Buletinul Comisiunii Monumentelor Istorice 1912, 5

Giurescu D. C., Ce a fost Partidul Comunist Român, "Clipa," available online: <http:// www.revistaclipa.com/2583/2009/12/repere-academice/ce-a-fost-partidul-comunist-roman > [accessed: 15 May 2013]

Hitchins K., A Concise History of Romania, Cambridge 2014

Iorga N., Les arts mineurs en Roumanie, vol. 1, Bucarest 1934; vol. 2, Bucarest 1936

Iorga N., Gh. Balş, Histoire de l'art Roumain anciènne. L'art roumain du XIVe au XIXe siècle: description et documentation historique, Paris 1922

Mihail I., "Pictura bisericii Domnești din Curtea-de-Argeș," Buletinul Comisiunii Monumentelor Istorice 1917-1923, 10-16

Musicescu A.-M., "Nicolae Iorga și studiul artelor în România," Studii și cercetări de istoria artei. Seria arta plastică 1966, 13(1)

Omagiu lui George Oprescu cu prilejul împlinirii a 80 de ani, eds. T. Vianu, M. Popescu, Bucureşti 1961

Onciul D., "Anul morții lui Negru Vodă," Buletinul Comisiunii Monumentelor Istorice 1917-1923, 10-16

Oprescu G., Arta țărănească la români, Bucureşti 1922

Oprescu G., Andreescu, Craiova 1931

Oprescu G., G. Petraşcu, Craiova 1931

Oprescu G., Anul artistic la noi şi la alţii. Studii şi impresii, București 1934

Oprescu G., L'art roumain de 1800 à nos jours, Malmö 1935

Oprescu G., Roumanian Art from 1800 to Our Days, Malmö 1935

Oprescu G., Samtida Konst i Romänien. Ett urval bilder med inledande text, Malmö 1935

Oprescu G., L'art du paysan roumain. Avec une preface de Henri Focillon, Bucarest 1937

Oprescu G., G. Petraşcu, Bucureşti 1940

Oprescu G., Peasant Art in Rumania. With a foreword by Henri Focillon, Bucharest 1940

Oprescu G., Grigorescu desinator, București 1941

Oprescu G., Camil Ressu, Bucureşti 1942

Oprescu G., Jean Al. Steriadi, Bucureşti 1942

Oprescu G., Ștefan Popescu, București 1942

Oprescu G., Pictura românească în secolul al XIX-lea², Bucureşti 1943

Oprescu G., La peinture roumaine contemporaine, Berne 1944

Oprescu G., Grafica românească în secolul al XIX-lea, vol. 1, București 1942; vol. 2, Bucureşti 1945

Oprescu G., Stoenescu, Bucureşti 1946

Opriş I., Ocrotirea patrimoniului cultural. Tradiții. Destin. Valoare, Bucureşti 1986

Petranu C., Muzeele din Transilvania, Banat, Crișana şi Maramureş. Trecutul, prezentul şi administrarea lor, București 1922

Petranu C., "Rolul istoricului de artă român în Transilvania," Cronica Numismatică şi arheologică 1923, 4

Petranu C., "Învățământul istoriei artelor la universitatea din Cluj," Vieața nouă 1924 
Petranu C., Învățământul istoriei artelor la Universitatea din Cluj, Bucureşti 1924

Petranu C., Bisericile de lemn din județul Arad, Sibiu 1927

Petranu C., Monumentele istorice ale județului Bihor, 1: Bisericle de lemn, Sibiu 1931

Petranu C., "L'art Roumain de Transylvanie," La Transylvanie 1938

Petranu C., Arta românească din Transilvania, Sibiu 1943

Petranu C., "Die alte kirchliche Kunst der Rumänen," in: idem, Ars Transsilvaniae, Etudes d'histoire de l'art transilvain. Studien zur Kunstgeschichte Siebenbürgens, Sibiu 1944

Petranu C., Ars Transsilvaniae. Etudes d'histoire de l'art transilvain. Studien zur Kunstgeschichte Siebenbürgens, Sibiu 1944

Petrașcu N., Pictorul Grigorescu, București 1895

Popescu M. "Cuvînt înainte," in: G. Oprescu, Pictura românească în secolul al XIXlea, Bucureşti 1984

Rampley M., "The Strzygowski school of Cluj. An episode in interwar Romanian Cultural policies," Journal of Art Historiography 2013, 8, available online: <https:// arthistoriography.files.wordpress.com/2013/06/rampley.pdf>

Simon C., Artă şi identitate națională în opera lui Virgil Vătăşianu, Cluj-Napoca 2002

Strzygowski J., Kunde, Wesen, Entwicklung. Ein Einführung, Wien 1922

Ștefănescu Delavrancea B., "Din viața lui Nicolae Grigorescu," Luceafărul 1905, 4(1)

Ștefănescu I. D., L'évolution de la peinture religieuse en Bucovine et en Moldavie depuis les origines jusqu'au XIXe siècle, Paris 1928

Ștefănescu I. D., L'évolution de la peinture religieuse en Bucovine et en Moldavie depuis les origines jusqu'au XIXe siècle. Nouvelles recherches. Etude iconographique, Paris 1929

Țoca V., "George Oprescu. Activitatea și crezurile sale în perioada interbelică," in: Istoria Culturii. Cultura istoriei. Omagiu Profesorului Doru Radosav la vârsta de 60 de ani, eds. I. Costea, O. Ghitta, V. Orga, I. Pop, Cluj-Napoca

T,oca V., "Old Romanian Art in Virgil Vătășianu's Works Between the Two World Wars and His Choice of Method," Studia Universitatis Babeș-Bolyai, Series Historia Artium 2012, 57(1)

Toca V., Art Historical Discourse in Romania, Budapest 2011

Vătășianu V., "Bolțile moldovenești, originea și evoluția lor istorică," Anuarul Institutului de Istorie Națională 1929, 5

Vătășianu V., "Contribuție la cunoașterea bisericilor de lemn din Moldova," in: Închinare lui N. Iorga cu prilejul împlinirii vârstei de 60 de ani, Cluj 1931

Vătășianu V., "Pentru originea arhitecturii moldovenești," in: Junimea Literară 1927, XVI

Vătășianu V., "Vechile biserici de piatră din județul Hunedoara," Anuarul Comisiunii monumentelor istorice. Secțiunea pentru Transilvania 1929

Vătășianu V., L'arte bizantina in Romania. I ricami liturgici, Roma 1945

Vătășianu V., Vechile biserici de piatră din județul Hunedoara, Cluj 1930

Vlahoutza A., N. I. Grigorescu, sa vie et son śuvre, Bucarest 1911

Vlahuță A., Pictorul N. I. Grigorescu, vieața și opera lui, București 1910 
Vlad Toca

University of Art and Design, Cluj-Napoca

ROMANIAN ART HISTORIOGRAPHY DURING THE INTERWAR PERIOD.

BETWEEN THE SEARCH FOR SCHOLARSHIP AND COMMITMENT TO A CAUSE

\section{Summary}

At the end of World War I, Romania emerged as a much stronger nation, with a greatly enlarged territory. During the two world wars, the Romanian state was permanently looking for the best way to preserve the newly created national state and defend its frontiers. This was the only matter all Romanian parties seemed to agree on. The threat of territorial revisionism coming from Hungary, the Soviet Union and, to a lesser extent, Bulgaria united all the political actors in defending the peace system of Versailles and supporting the League of Nations as the guarantor of this peace and stability.

The interwar period was a remarkable time for Romania's cultural history. Between the two world wars, the Romanian cultural scene was dominated by what Keith Hitchins calls the 'Great Debate' about national identity and development. The opponents were those advocating synchronism with the West, on the one hand, and those pleading for tradition, on the other, with many others looking for a third way. In Romanian interwar culture, the country's modernity was emphasized in order to place the country within the larger family of European nations. An opposing, and at the same time, complementary line of thought was that of presenting the long and noble Romanian history, tradition and ancestral roots.

These two themes have been present in Romanian culture since the mid-19 ${ }^{\text {th }}$ century. They were used by various authors, sometimes in a complementary fashion, while at others, in a conflicting manner in literature, historical writing or political discourse. This process did not end with the creation of the Greater Romania after the end of World War I. New threats, which are mentioned above, maintained the need to continue this discourse. In this context, historical arguments became political arguments and were used by the Romanians in order to justify the new territorial gains and the Versailles system. Art history, part of the family of historical disciplines, came to play an important part in this.

Romanian art historical writing did not exist as such until the end of the $19^{\text {th }}$ century. It was only in the first years of the next century that the number of scholarly works produced following western standards steadily increased. As part of a general tendency of aligning Romanian academic practices with those in the West, art historiography established itself as a respectable academic discipline, a process which went hand in hand with the establishment of new institutions such as museums, university departments, research institutions and the Commission for historical monuments. All these institutions were founded and financed by the Romanian state, and most scholars were involved with these institutions in one way or another. 
Although Romanian art historiography of the period is dominated by the desire to produce academic works to the highest standards, the ideas of the Great Debate are present in the works of that time. At the same time, in several texts, the most prominent art historians of the day strongly affirm the necessity of putting their work in the service of the national cause. In this paper, we will be looking at the general histories of Romanian art written between the two world wars. The choice of these texts is motivated by the fact that these works are the result of larger research projects and have a broader scope and as such better summarise the trends of the interwar period.

Keywords:

Romanian art historiography; interwar period; Romanian art; Transylvanian art; Romanian culture 